\title{
Contribution to the knowledge on distribution in Hungary and habitat preferences of Gnaphosa modestior Kulczyński, 1897 a little-known spider species
}

\author{
TÜNDE SZMATONA-TÚRI ${ }^{1}$ \\ GÁBOR KOVÁCS ${ }^{2}$ \\ DIÁNA VONA-TÚRI ${ }^{3}$ \\ GÁBOR MAGOS ${ }^{4}$ \\ ${ }^{1}$ FM ASzK - Forestry, Agricultural and Game \\ Management Training School and Student Hostel \\ of Mátra, 11 Erdész street, H-3232Mátrafüred, \\ Hungary, E-mail: turitunde79@gmail.com \\ ${ }^{2}$ Londoni krt. 1., Szeged H-6724 Hungary, \\ E-mail: gabor.kovacs.arachnida@gmail.com \\ ${ }^{3}$ Eötvös József Reformated Education Centre, \\ 29 Dobó Street, H-3360 Heves, Hungary, \\ E-mail: turidiana79@gmail.com \\ ${ }^{4}$ Bükk National Park Directorate, Mátra Region, \\ 6 Sánc road, H-3304 Eger, Hungary, \\ E-mail: magosg@bnpi.hu,

\section{Correspondence:} \\ Tünde Szmatona-Túri \\ E-mail: turitunde79@gmail.com
}

Key words: Rare species; taxonomical status; Europe; grassland managements

Received May 21, 2017.

Revised July 03, 2018.

Accepted April 30, 2019.

\begin{abstract}
Background and purpose: The aim of this review is to present current knowledge on the occurrence of a little-known gnaphosid species Gnaphosa modestior Kulczyński, 1897. Early it was mentioned as G. alpica species in Middle Europe. In this study, we reported the new occurrence of this species in Hungary and we examined of the effect of shrub control and mowing on this species abundance.
\end{abstract}

Materials and methods: Our arachnological research was conducted in the Mátra Mountains, the highest range of volcanic massin northern Hungary, between 2007 and 2016.

Result and conclusion: We recorded 13 specimens from five habitats of the southern part of the Mátra Mountains. This species can be found mainly in untreated shrubby habitats from April to June. In general, it can say that $\mathrm{G}$. modestior is a stenochronous spider species which lives in habitats not influenced by human activities in the Mátra Mountains. However, this attributes of species differ in some European countries.

\section{INTRODUCTION}

naphosa Latreille, 1804 is a large Holarctic genus of ground-dwellTing spiders (family Gnaphosidae) with 146 described species (1). Besides G. modestior Kulczynski, 1897 eight species of the genus Gnaphosa have been reported in Hungary: G. alpica Simon, 1878, G. bicolor (Hahn, 1833), G. lucifuga (Walckenaer, 1802), G. lugubris (C.L. Koch, 1839), G. microps Holm, 1939, G. mongolica Simon, 1895, G. opaca Herman, 1879 (2) and G. rufula (L. Koch, 1866) (3).

Gnaphosa modestior is a rare European gnaphosid spider species (4). It's occurrence data are known from Szerencs of Hungary ( 5 as Gnaphosa laeta), Đakovó in Croatia, Balatonalmádi in Hungary, Baziás in Romania (5), Lobau and Leitha Mountain in Austria (4), Calabria in Italy (6), Slovenia (7), Czech Republic (8).

Hungarian occurrence of species are from Péter Hill in Balatonarács, Apró Hills in Balatongyörök, Somló in Doba, Pető Hill in Gyenesdiás, Szarvaskő, Bélkő and Molnár rock in Bükk Mountain (9 as Gnaphosa laeta), also, Nagypirit (10), Téglavetö-dülő in Somlójenő (11), Nagybajom (12) and Háros Island (13). In the past the species was synonymized a couple of time as G. laeta (5) and as $G$. modestior $(4,5,14)$ and as $G$. alpica (15). After revalidation in 2018 (16) it is G. modestior again. 
The Mátra region is part of Northwestern Carpathians located in northeastern Hungary (Figure 1). This mountain has typical Pannon biogeographical characteristics in vegetation aspect consisting different plant species and phytocoenosis close to each other by this forming diverse vegetation (17). The whole Mátra Mountains is Special Protection Area (SPA) designated respectively under the Habitat Directive as a part of the Natura 2000 network, the aim of which is the protection of biodiversity and conservation of natural habitats and rare and vulnerable species (18). In the Mátra Mountains grassland managements are used in order to save the original grassy habitats and by this maintain the habitats for several rare and protected species. This reconsructional and maintenance work was coordinated and supported by Mátra Landscape Protection Area.
The original goal of this research is an examination of the effect of shrub control and mowing on spider communities, during which $G$. modestior specimens were recorded. This study reveals the habitat preference and susceptibility to interference of $G$. modestior in the Mátra Mountains. Also, this paper represents the habitus and genitalia photos of the species.

\section{MATERIALS AND METHODS}

Twenty sampling sites were selected in the Mátra Mountains. Double-glass pitfall traps filled with ethylene glycol were established on 20 sampling sites between 2012 and 2016. Five traps were settled from each other 4-5 m along a transect. The traps were deployed twice (AprilJuly, September-November) over a six week period each

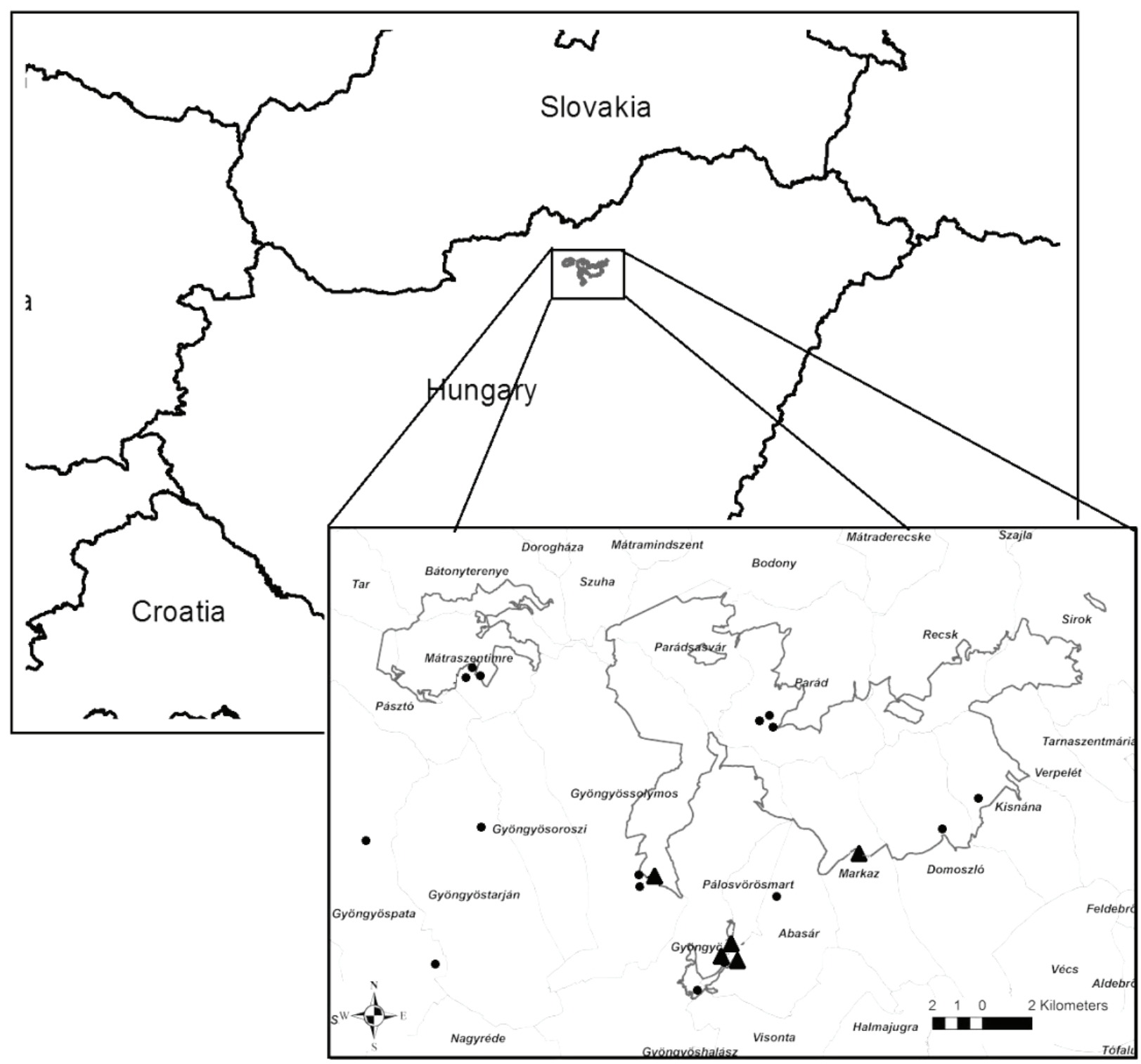

Figure 1. Occurrence data of Gnaphosa modestrior Kulczyński in the Mátra Mountains. ( $\mathbf{\Delta}$ : G. modestior is present, $\bullet$ : G. modestior is absent) 
a)



b)

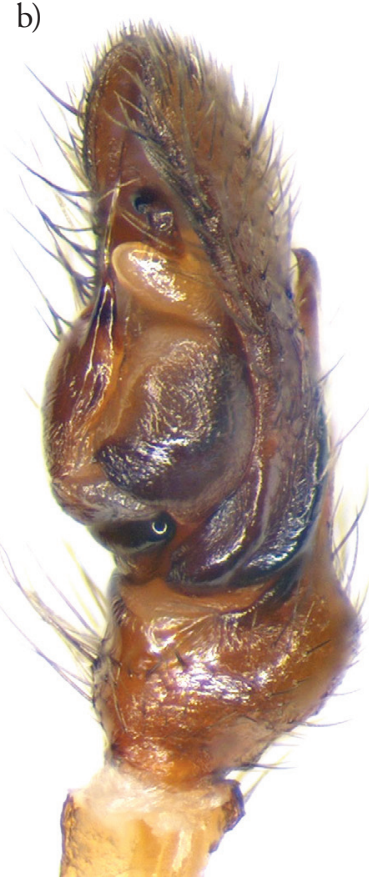

Figure 2. Gnaphosa modestrior Kulczyński: habitus (A), pedipalp (B), epigyne (C) and vulva (D).

year. Individuals were stored in $75 \%$ ethyl-alcohol. The specimens were identified using the available identification keys on the web page „Spiders of Europe” (19). Specimens and copulatory organs were studied using a Leica MZ FL III stereomicroscope and photographed by Canon Q Imaging Micro 5.0 RTV at the Institute of Genetics, Biological Research Centre (BRC, Szeged).

\section{RESULTS AND DISCUSSION}

The occurrence of $G$. modestior has never been recorded in the Mátra Mountains, where previously Chyzer \& Kulczinsky (20) and Kolosváry (21) made an arachnological research which listed 33 spider species including only one gnaphosid species: Kishidaia conspicua (L. Koch, 1866).

During the pedofaunistic monitoring between 2012 and 2016 a total of 13 specimens (10 males, 3 females) of $G$. modestior were found. This species was collected among 20 habitats only in 5 habitats of southern part of the Mátra Mountains (Figure 1). G. modestior is a stenochronous species which can be collected from April to August (9, 22), nevertheless it was mentioned as thermophilic species in the study of Steinberger (23). This is supported by this research according to which it was seen mainly from April to June (Table 1).

Taxonomic status of $G$. alpica was unclear untill these year. Early was mentioned as G. alpica species in Middle


Europe. Study of Dankaninová \& Gajdos (24) revealed the species in vineyard terraces of the Little Carpathians, in this study the question mark next to species name may show the uncertainty of species. Authors of the Italian checklist refers to that the Italian record of $G$. modestior has to be listed as G. apica (6). Both species have the similar color pattern characterized by dark brown-red to black-brown body with yellowish legs. But two species can easily be distinguished. $G$. modestior has much longer retrolateral tibial apophysis of males and much longer epigynal hood of females. It's vulva is reddish brown. Body length of males is $8-9 \mathrm{~mm}$, while females are 8-9,2 $\mathrm{mm}$ in length (19) (Figure 2).

The habitat preferences of the species have rarely been recorded. During the sampling, the most collected specimens were found in shrubby habitats (Table 1, Figure 3). Similarly to our data, Steinberger (23) recorded the species in edges and forests in Austria while Loksa (9) revealed it from low forests in Hungary. Besides these, species less frequently in open habitats of mainly grass steppe $(25,26)$ and sandy grassland (27) in the Czech Republic. In Slovakia, it lives in uncultivated and wired vineyards, and rocky habitats with shrubs and forest vegetation as well as on rocky walls without vegetation $(28,24)$.

Besides $G$. modestior among the genus Gnaphosa, only $G$. lucifuga can be found in the Mátra Mountains. Phenology of two species is different: G. lucifuga is a diplo- 
Table 1. A list of sampling sites with types of habitat where Gnaphosa modestior Kulczyniski were collected in Hungary.

\begin{tabular}{|c|c|c|c|c|}
\hline Localities & Sampling sites & Plant community & Number & Sampling year and months \\
\hline \multirow{3}{*}{$\begin{array}{l}\text { Sár Hill Nature } \\
\text { Reserve }\end{array}$} & Shrub & Pruno spinosae-Crataegetum Soó (1927) 1931 & $6 \hat{0}, 29$ & $\begin{array}{l}2012(06.08) \\
2013(05.10,05.24) \\
2014(05.20,06.06,06.26)\end{array}$ \\
\hline & Meadow & $\begin{array}{l}\text { Pulsatillo montanae-Festucetum rupicolae (Dostál } \\
\text { 1933) Soó } 1964 \text { corr. Borhidi } 1997 \text { - Pruno } \\
\text { spinosae-Crataegetum Soó (1927) } 1931\end{array}$ & $10^{\pi}$ & $2012(05.26)$ \\
\hline & Cleared shrub & $\begin{array}{l}\text { Pulsatillo montanae-Festucetum rupicolae (Dostál } \\
\text { 1933) Soó } 1964 \text { corr. Borhidi } 1997\end{array}$ & $10^{\lambda}, 1$ 우 & $2013(06.26)$ \\
\hline Gyöngyös-solymos & Shrub & $\begin{array}{l}\text { Pruno spinosae-Crataegetum Soó (1927) 1931with } \\
\text { forest steppe items e.g. Acer tataricum }\end{array}$ & $10^{\lambda}$ & $2012(05.26)$ \\
\hline Markaz & Clearing forest & $\begin{array}{l}\text { Corno-Quercetum pubescentis Jakucs \& Zólyomi } \\
\text { ex Máthé et Kovács } 1962\end{array}$ & $10^{\lambda}$ & $2014(04.28)$ \\
\hline
\end{tabular}

chronous species which can be collected from May-July and September. Also, habitat preference is differed in this area in that the $G$. lucifuga lives mainly in open habitats which are maintained by mowing.

Susceptibility to interference of $G$. modestior less information has been known. Based on occurrence data of species can be concluded wide scale of the naturalness of its habitats such as vineyards or mountain habitats. According to some studies the species tolerates minimal human activity such as mowing (25) and can be found in disturbed areas such as vineyards, and sand - and stone pits (26), also formerly arable field and its ecotones (27). This research targeted the examination of the effect of grassland management such as mowing and shrub control on spiders. According to our data treatment has not positive effect on abundance because the most individuals were collected in untreated habitats minimally influenced by human activities. Similarly to Steinberger (23), who says that this species prefers natural habitats. Presence of G. modestior is not surprising in Sár Hill Nature Reserve which is southern edge hill of Mátra. This has specific biogeography situation allowing the mixing of the conti-

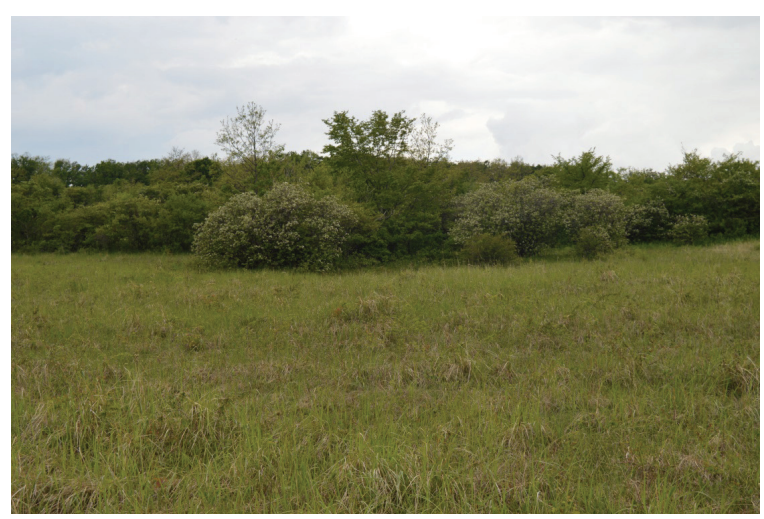

Figure 3. The shrubby habitat of Gnaphosa modestior Kulczyński in the Sár Hill Nature Reserve of the Mátra Mountains. nental and piedmont species, many rare and protected plant and animal species live in this area. Also, the hill is significant in arachnological respect besides protected Nemesia pannonica Herman 1879 (29) providing habitats for more rare and protected spider species (30).

It can be said, $G$. modestior is a stenochronous species which was recorded firstly in the Mátra Mountains. This rare and little known species in Europe lives in several habitat types, prefers natural habitats but succesfully adapts to former disturbed habitats, as well. The aim of shrub control as grassland management is the maintenance of mountain meadows but some valuable species such as $G$. modestior prefers shrubby habitats. Therefore it is worth considering the suitable coordination of shrub control and maintaining mosaic habitats because of different habitat demands of rare and protected spider species.

\section{ACKNOWLEDGEMENTS}

We thank Gábor Vári and Henrik Gyurkovics (BRC, Szeged) for genitalia photos. We also thank László Urbán for sampling.

\section{REFERENCES}

1. World Spider Catalog 2017 Natural History Museum Bern, online at http://wsc.nmbe.ch version 18.0, accessed on 2017

2. SAMU F, SZINETÁR CS 1999 Bibliographic check list of the Hungarian spider fauna. Bull. Br. Arachnol. Soc. 11(5): 161-184

3. SZITA É, SAMU F, SZINETÁR CS, DUDÁS G, BOTOS E, HORVÁTH R, SZALKOVSZKI O 2006 New data on the occurrence of Gnaphosa rufula (L. Koch, 1866) and Gnaphosa mongolica Simon, 1895 in Hungary (Araneae: Gnaphosidae). In: DELTSCHEV C, STOEV P (eds) European Arachnology 2005. Acta Zool Bulg. 329-334

4. GRIMM U 1985 Die Gnaphosidae Mitteleuropas (Arachnida, Araneae). Abhandl. Naturwissen Vereins Hamburg (NF) 26: $1-318$

5. CHYZER C, KULCZYŃSKI W 1897 Araneae hungariae. Budapest, 2: 151-366 Simon E 1878 Les arachnides de France. Paris 4: $1-334$ 
6. PANTINI P, ISAIA M (2017) Checklist of the Italian spiders (version May 2017). online at

http://www.museoscienzebergamo.it/web/index.php?option=com_content\&view=category\&layout $=$ blog $\&$ id $=96 \&$ Itemid $=94$

7. KOSTANJŠEK R, KUNTNER M (2015) Araneae Sloveniae: a national spider species checklist. ZooKeys 474: 1-91. https://doi.org/10.3897/zookeys.474.8474

8. Czech Arachnological Society. https://arachnology.cz/druh/gnaphosa-modestior-969.html

9. LOKSA I 1966 Die bodenzoozönologischen Verhältnisse der Flaumeichen-Buschwälder Südostmitteleuropas. Akadémiai Kiadó, Budapest

10. SZINETÁR CS, KOVÁCS P 2003 Az arachnológiai vizsgálatok eredményei. In: Kenyeres Z, Bauer N (eds) Az Agrár-környezetvédelmi Program ÉTT programjának támogatásával fenntartott Marcal-menti élőhelyek természetvédelmi szempontú monitorozása. Kézirat, p 52

11. KOVÁCS P 2009 Somlójenői hulladéklerakó környezetének arachnológiai vizsgálata. Kézirat, p 12

12. SZINETÁR CS 1992 A Boronka-melléki Tájvédelmi Körzet pókfaunája. Dun. Dolg. Term. Tud. Sor. 7:331-345

13. LOKSA I, LOKSA I 1991 Adatok a Háros-sziget ízeltlábú faunájához. Kézirat 94-105

14. HEIMER S, NENTWIG W 1991 Spinnen Mitteleuropas: Ein Bestimmungsbuch. Paul Parey, Berlin, p 543

15. OVTSHARENKO V I, PLATNICK N I, SONG D X 1992 A Review of the North Asian round spiders of the Genus Gnaphosa (Araneae, Gnaphosidae). Bull. Am. Mus. Nat. Hist. 212: 1-88

16. ŘEZÁČ M, RŮŽIČKA V, OGER P, ŘEZÁČOVÁ V 2018 European species of the Gnaphosa alpica complex (Araneae, Gnaphosidae). Zootaxa 4370 (3): 289-294. https://doi.org/10.11646/zootaxa.4370.3.9

17. VOJTKÓ A, SHRAMKÓ G, MAGOS G, HARMOS K 2010 Növényvilág. In: BARÁZ CS, DUDÁS GY, HOLLÓ S, SZUROMI L, VOJTKÓ A (eds) A Mátra Tájvédelmi Körzet. Heves és Nógrág határán. Bükki Nemzeti Park Igazgatóság. p 149-174

18. MAGOS G, SZABÓ SZ, SZUROMI L, URBÁN L 2010 Természetvédelem a Mátrai tájegységben. In: BARÁZ CS, DUDÁS GY, HOLLÓ S, SZUROMI L, VOJTKÓ A (eds) A Mátra Tájvédelmi Körzet. Heves és Nógrág határán. Bükki Nemzeti Park Igazgatóság. p 373-398

19. NENTWIG W, BLICK T, GLOOR D, HÄNGGI A, KROPF C Spiders of Europe. online at www.araneae.unibe.ch. Version of 04. 2017.
20. CHYZER K, KULCZYNSKI U 1918 Ordo Araneae. A Magyar Birodalom Állatvilága. III. Arthropoda. K. M. Természettudományi Társulat. Budapest. 1920

21. KOLOSVÁRY G 1935 Beiträge zur Spinnenfauna des Mátragebirges un der Villányer Gegend. Folia Zool. et Hydrobiol 8: 267278

22. THALER K, KNOFLACH B 2004 Zur Faunistik der Spinnen (Araneae) von Österreich: Gnaphosidae, Thomisidae (Dionycha pro parte). Linzer biol. Beitr. 36/1: 417-484

23. STEINBERGER K H 2004 Zur Spinnenfauna der Parndorfer Platte, einer Trockenlandschaft im Osten Österreichs (Burgenland) (Arachnida: Araneae, Opiliones). Denisia 12, zugleich Kataloge der OÖ. Landesmuseen Neue Serie 14: 419-440

24. DANKANINOVÁ L, GAJDOŠ P 2012 EpigEické pavúky historických štruktúr polnohospodárskej krajiny (vinohradnícka krajina svätý jur). Folia faunistica Slovaca 17 (3): 275-290

25. KOŠULIČ O, HULA V 2012 Investigation of spiders (Araneae) of the Nature Monument Jesličky (South Moravia, Czech Republic). Acta Univ. agric. Silvic. Mendel. Brun. 60: 125-136. https://doi.org/10.11118/actaun201260050125

26. ŘEZÁČ M 2013 Problematika druhů Gnaphosa alpica a G. modestior. In: Pavouk. Zpravodaj České arachnologické společnosti. č 35,4 .

27. HULA V, NIEDOBOVÁ J, H. ŠEFROVÁ 2014 Remarkable spiders of artifical sandy grassland near town Hodonin (Czech Republic). Acta Univ. Agric. Silvic. Mendel. Brun. 62: 99-115. https://doi.org/10.11118/actaun201462010099

28. GAJDOŠ P, DANKANINOVÁ L 2010 Epigeické pavúky ve vazbe na vinohradnické historické krajinné struktury (modelové území Svätý Jur) (The epigeic spiders communities in relation to vinery historical landscape structures (model area Svätý Jur)) In: Medzinárodná vedecká konferencia doktorandov, mladých vedeckých a pedagogických pracovníkov. Nitra: Faculty of Natural Sciences, Constantine the Philosopher University, p 201-209.

29. SZMATONA-TÚRI T, VONA-TÚRI D 2012 A magyar aknászpók (Nemesia pannonica Herman, 1879) újabb előfordulása Magyarországon. Természetvéd. Közl. 18: 480-486

30. CSÓKA GY, DUDÁS GY, FÖLDESSY M, KOROMPAI T, KOVÁCS T, MELIKA G, NAGY A, NÓGRÁDI S, RÁCZ I A, SZABÓKY CS, SZMATONA-TÚRI T, TÓTH S, UHERKOVICH Á, VARGA A 2010 Állatvilág-Gerinctelenek. In: BARÁZ CS, DUDÁS GY, HOLLÓ S, SZUROMI L, VOJTKÓ A (eds) A Mátra Tájvédelmi Körzet. Heves és Nógrág határán. Bükki Nemzeti Park Igazgatóság. p 181-210 